\title{
The Development of Miniaturized Extraction Tool for the Gene Biosensor
}

\author{
Haemyun Kwon, Hỵojung Kim, and Yongseong Kim* \\ Department of Chemistrv. Kumgnam Cniversity, Masan 631-701. Korea. ${ }^{\circ}$ E-mail: kimusiä kumgnamac.kr \\ Received Angust 17, 2007
}

Key Words : DNA, Extraction. PCR. Capillary, Photopolymerization

Analysis of DNA has represented the deep insight of diagnostic and clinical information in individuals for detecting and treating genetic diseases related to loss of heterozy'gosity. mutation. gene copy number and genotype ${ }^{1-3}$ Traditional DNA assay's involve extraction of DNA from whole blood. amplification by the polymerase chain reaction. ${ }^{4}$ and subsequent separation using slab gel electrophoresis. "Although this process is known to be reasonably successful, it is generally time-consuming and unsuitable for high-throughput analy'sis. ${ }^{6}$ A smaller reaction volume would be beneficial to reduce the cost of reagents and the amount of waste generated. Extraction of DNA from cellular constituents is also a key for most nucleic acid-based drug discovery and clinical diagnostic applications. ${ }^{7}$ It is important that inhibitors or interfering substances from the cells and extracellular environment should be removed prior to PCR analysis. ${ }^{\S}$ Traditionally. the organic-based extraction and ethanol precipitation have been used to isolate and concentrate DNA prior to digestion and amplification. Although this procedure could handle about 10 to $20 \mu \mathrm{L}$ of blood. it costs time and efforts due to many steps including cells lysis. several unltracentrifuges and precipitations. ${ }^{5 . j 0}$ Commercial kits such as Qiagen DNA Stool Mini Kit and QIAamp DNA kit have provided relatively good extraction efficiency. however. drawbacks are increasing number of steps (more than 20 steps) for blood treatment and large sample volume (more than $250 \mu \mathrm{L}$ ). ${ }^{11.12}$

Several papers have been reported in order to overcome the disadvantages of the extraction of DNA from whole blood. For example dendrimer-modified bacterial magnetic particles were employed based on the interaction of negatively-charged DNA and cations on dendrimer. ${ }^{13-15}$ This electrostatic interaction was also utilized on amino silane coated-polydimethylsiloxane (PDMS) microchip with the blood volume of less than $20 \mu \mathrm{L} .^{15.16}$ Glass microchip with heat-treated frit was used for the extraction and detection of DNA from spores of the vaccine strain. Although somewhat effective extraction was achieved with magnetic particles or microchips. many shortconings such as long modification time. intricate control of coating and high cost for microchip production should be considered before the experiment. Recently. DNA purification process with adsorption of DNA onto a solid surface via hydrogen boding to silica and via electrostatic interactions has been developed. ${ }^{17.18}$ This approach allows inhibiting species to be removed before the purified DNA is eluted from the surface and affords the opportunity for miniaturization.

In this paper. a capillary-based DNA extraction tool was developed for the blood volume of less than $3 \mu \mathrm{L}$. Only 3 steps were required before PCR amplification of extracted DNA. Glutathione-S-transferase genes related to bladder and breast cancer was tested with our extraction tool. The conditions for frit formation by photopolymerization including the ratios of photoinitiators. the frit length. UV exposure time and the size of the silica bead particles were examined and optimized.

Figure 1 shows our miniaturized extraction tool using fused-silica capillary tube ( $520 \mu \mathrm{m}$ i.d.). As shown in Figure 1(a) and (b), the tool was built with two parts: the region for silica particles and the frit for packing of the particles. Packed silica particles provide the isolation and extraction of genomic DNA while the frit holds the silica particles. Compared to the sleeve type packing with glass fiber. ${ }^{17}$ our tool is simpler in construction, and easier to fill the particles in the capillary tube.

For the construction of the frit. the choice of the photoinitiator is important. Bis acyl phosphine or $\alpha$-hydroxyketone is a well-known chemical class that absorbs UV energy from the light source and initiates the radical polymerization that converts the liquid formulation to a solid. cured film. In our experiment. it was found that the ratio of the IRGACURE solutions played a critical role in the fomation of the frit. When either IRGACURE $184(\alpha-$ hydroxyketone) or IRGACURE 819 (bis acyl phosphine) as shown in Figure 2 was tested as the curing agent. the frit formation was failed. Since the manufacturer recommended the use of IRGACURE 184 in combination with IRGACURE

(a)

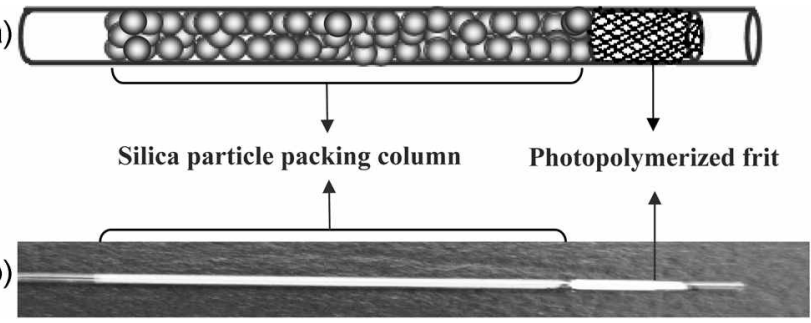

Figure 1. Schematic of the miniaturized DNA extraction tool (a) and the real picture (b). Capillary tube; $520 \mathrm{tm}$, i.d., total length of the capillary: $10 \mathrm{~cm}$, the size of the silica bead: $15, \mathrm{~km}$, the length of the bead-packed region; $3.0 \mathrm{~cm}$, the length of the photopolymerized region; $3.0 \mathrm{~mm}$, the ratio of $1 \mathrm{RGACURH} 184$ to IRGACURE $819 ; 4: 1$. 
<smiles>O=C(c1ccccc1)C1(O)CCCCC1</smiles>

IRGACURE 184

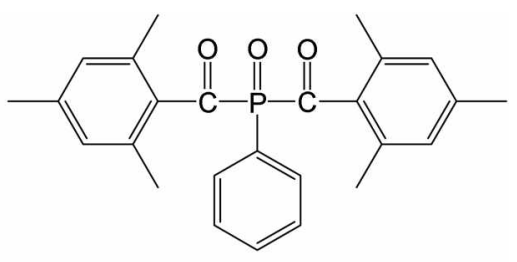

IRGACURE 819
Figure 2. Chemical structure of IRGACURE 184 (1-hydroxycyclohexyl-pheny l ketone) and IRGACURE 819 (phenyl bis $(2,4,6-$ trimethyl benzoyl) phosphine oxide).

819 for good surface hardness. we have tried many different ratios of both curing agents. It was observed that the ratios other than 4:1 of IRGACURE 184 and IRGACURE 819 did not provide the solid formation of the stable frit. Although the reason was not clear yet, we believe that the wavelength and the power of the UV lamp might be related to the activity of the curing agents.

During photopolymerization process. the effect of UV exposure time was investigated by obtaining the image of scanning electron micrograph. As shown in Figure 3(b). UV exposure time between 15 to $20 \mathrm{~min}$ produced the stable frit successfully. When the exposure time was relatively short (Figure 3(a)). the frit was not properly fonned. When the exposure time was more than $20 \mathrm{~min}$, the packing of the silica particles became strenuous due to high back pressure against the frit. It was observed that the length of the frit was also significant. As shown in Table 1, the stability of the frit was determined by the length of the photopolymerized frit. For the frit length of shorter than $3.0 \mathrm{~mm}$. the stability of the frit was weak. resulting in the breakage of the frit structure.
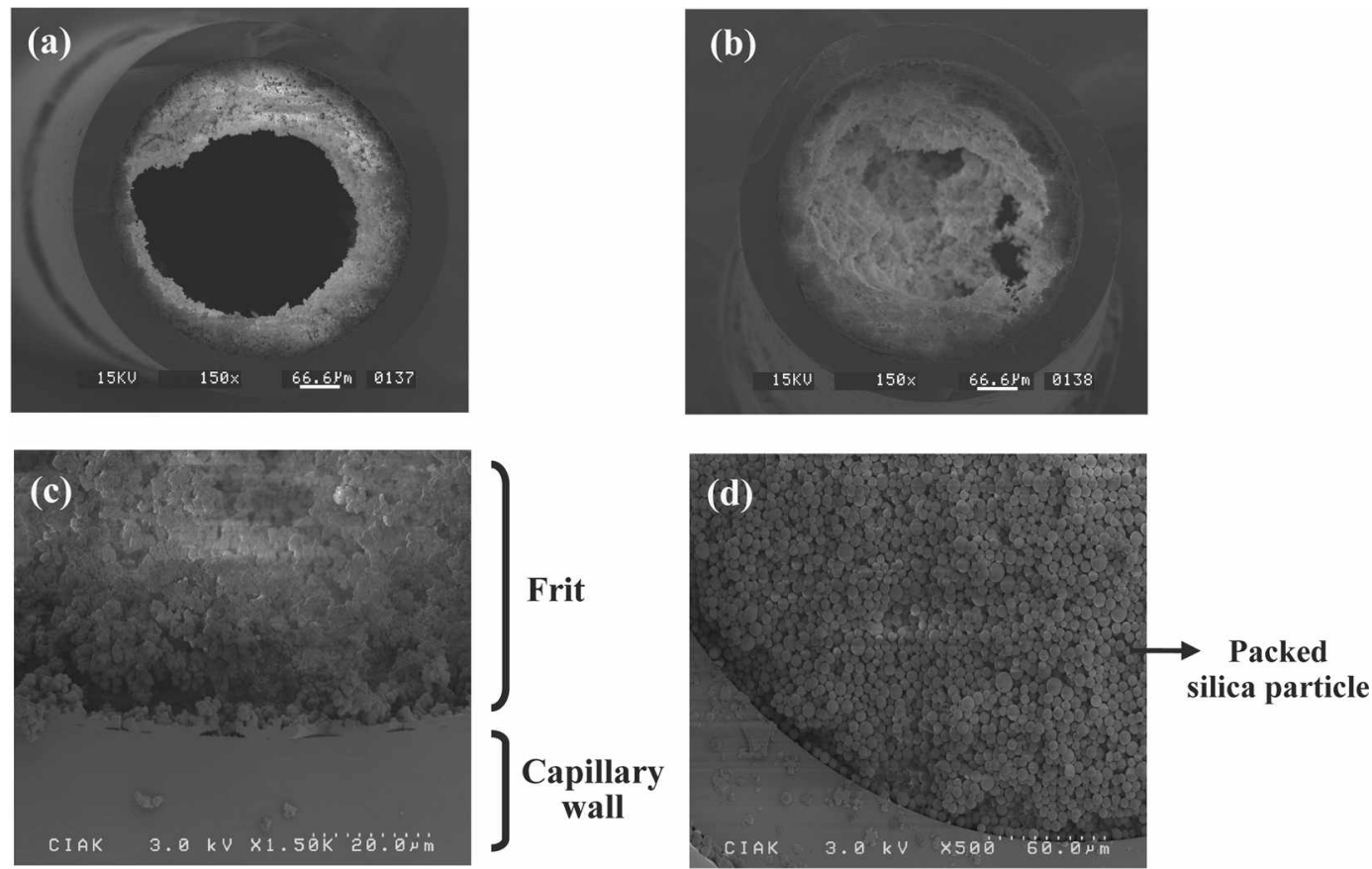

Table 1. Stability of photopolymerized trit length

\begin{tabular}{cc}
\hline $\begin{array}{c}\text { Photopolymerized frit } \\
\text { length }(\mathrm{mm})\end{array}$ & Stability of photopolymerized trit \\
\hline 1.0 & very weak \\
2.0 & weak \\
3.0 & stable \\
4.0 & low back pressure \\
5.0 & high back pressure \\
\hline
\end{tabular}

When the length was larger than $3.0 \mathrm{~mm}$, the back pressure became stronger, which made the packing of the silica particles problematic.

It seemed that the size of the silica particles did not cause much variation in the yield of DNA extraction. We have employed the silica particles of 5.0 or $15 \mu \mathrm{m}$ diameter for the same volume of the capillary tube, and it turned out that the results of PCR amplification were similar. However. the fixation of the silica particles in the capillary tube was important. When only silica slurry was introduced and dried. the packing of the silica bead particles became less dense, resulting in irreproducible DNA extraction. As shown in Figure 4, hydrolyzed tetraethoxysilane (TEOS) not only provides more hydroxyl groups for DNA binding. ${ }^{5.18}$ but also fixes silica beads in place generating more dense packing (see Figure 3(d)).

In order to confirm the applicability of our capillary-based miniaturized tool for DNA extraction to the real blood sample, two genes (GSTMl and GSTT1) from glutathioneS-transferase (GST) were selected as the test DNA. It is known that deletion of GSTMI or GSTTl may cause the cancer due to malfunction of glutathione-S-transferase. a

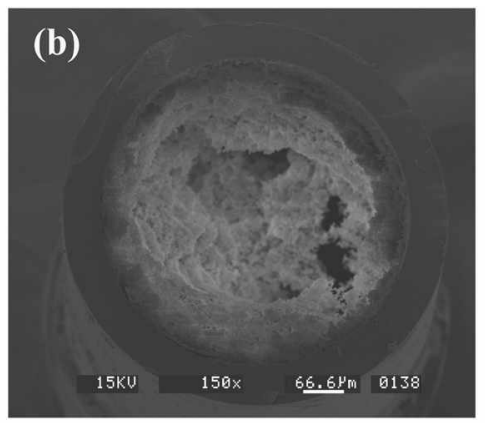

Figure 3. Scanting Electron Microscopy (SEM) inages of the frit and the silica bead packing. (a) UV exposure time $5 \mathrm{~min}$ to $10 \mathrm{~min}, 150 \mathrm{X}$ magnification, (b) UV exposure time $15 \mathrm{~min}$ to $20 \mathrm{~min}, 150 \mathrm{X}$ magnification (c) $1500 \mathrm{X}$ magnification of (b), (d) silica bead packing, $500 \mathrm{X}$ magnification. SEM acceleration voltage: $10-30 \mathrm{kV}$. 


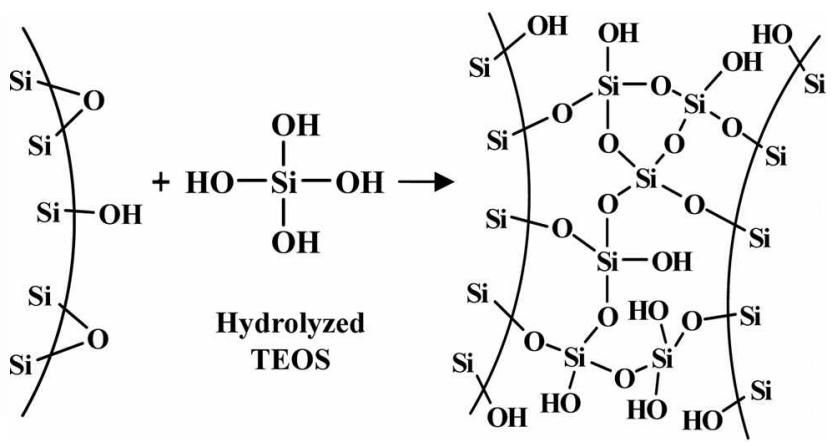

Silica bead

Figure 4 . Schematic of the fixation of silica beads by hydrolyzed tetraethoxysilane (TEOS).

xenobiotic metabolizing enzyme that deactivates carconogens or procarcinogenic compounds or protects cells from oxidative stress. ${ }^{19,10}$ Figure 5 shows the analysis of GSTMI and GSTTl from $3 \mu \mathrm{L}$ of blood. $\beta$-Globin was used as the internal standard. It was obvious that GSTT1 was deleted for one individual (Figure 5(a)), while both GSTMI and GSTTI were missed for the other individual (Figure $5(\mathrm{~b})$ ). For the individual in Figure 5(c). it was clearly seen that GSTMl was missed. Figure 5 shows that a genetic polymorphism for glutathione-S-transferase could be verified with our lab-ona-chip system for different individuals

Our capillary-based miniaturized DNA extraction tool was successfully applied to the analysis of genes from human blood. Since the blood volume of less than $3 \mu \mathrm{L}$ was required, the potential for reducing pain for the patients. decreasing waste disposal. and shortening the process time for DNA extraction would be excellent. Compared to the polyethylene sleeve type extraction tool reported by Tian's group. ${ }^{17}$ our miniaturized tool turned out to be simpler to construct and more efficient to perform DNA extraction_due to reduced instability of microparticle bead bed using TEOS silica "glue". Also, our capillary-based system is much cheaper to prepare than a microchip-based one ${ }^{5,18}$ since the photolithographic process for the microchip production is generally' more expensive. Integration of this miniaturized extraction tool to genetic disease diagnosis using lab-on-a-chip is under progress in our laboratory:

\section{Experimental Section}

Chemicals. Tetraethoxysilane (TEOS), guanidine hydrochloride (GuHCl), Triton-X 100, Tris(hydrosymethyl)aminomethane. boric acid. 3-(trimethoxysilyl)propyl methacrylate (TMSPM), ethylenediaminetetraacetate (EDTA). ethidium bromide (EB). poly (ethylene oxide) (PEO. $\mathrm{Mw}=8.000,000$ ). toluene, 2-propanol. hydrochloric acid, nitric acid were obtained from Signa-Aldrich. Co. (MO. USA). A monomeric dsDNA intercalating dye (EB) is mutagenic and carcinogenic so that a pair of lab-glove should be used during treatment. For DNA extraction. either TE ( $10 \mathrm{mM}$ Tris. 1 mM EDTA) or $1 \mathrm{x}$ TBE ( $89 \mathrm{mM}$ Tris. $89 \mathrm{mM}$ borate. $2.0 \mathrm{mM}$ EDTA) were employed.

Bare fused silica capillariey with $520 \mu \mathrm{m}$ i.d. was purchased from Polymicro Technologies (Phoenix. AZ, USA). Glass capillary tubes with $1.1 \mathrm{~mm}$ i.d. were from Scientific Glass Inc. (Rockwood. USA). IRGACURE 184 and 819 as a photoinitiator were acquired from Ciba Specialty Chemicals Inc. (Basel. Switzerland). Silica particles with either $15 \mu \mathrm{m}$ or $5 \mu \mathrm{m}$ diameter were obtained from Daiso Co. (Osaka, Japan). PCR premix and glutathione-S-transferase (GST) were from Bioneer. Co. (Daejeon, Korea). Deionzed water (Mili-Q reagent water system. MA. USA) was used throughout the experiment.

Miniaturized extraction tool. The sol-gel solution was made up of $750 \mu \mathrm{L}$ of 3-(trimethoxysilyl)propyl methacrylate, $22.5 \mu \mathrm{L}$ of $0.12 \mathrm{M}$ hydrochloric acid, and $225 \mu \mathrm{L}$ of water. This solution was stirred for $30 \mathrm{~min}$ in the dark at room temperature. A $170 \mu \mathrm{L}$ of toluene was added to $30 \mu \mathrm{L}$ of the sol-gel solution and stirred for $30 \mathrm{~min}$ at room temperature. A $1.78 \mathrm{mg}$ of IRGACURE 819 and a $7.12 \mathrm{mg}$ of IRGACURE 184 were added to the toluene mixture. Then, this IRGACURE solution was stirred for $l \mathrm{~h}$ at room temperature and stored at dark for later use.

A $3.0 \mathrm{~mm}$ window was made at the end of the $520 \mu \mathrm{m}$ i.d. polyimide-coated capillary tube using a torch. After IRGACURE solution was filled inside the capillary tube. both ends of the capillary were sealed with parafilm prior to UV exposure for 15 min by Deuterium lamp (E8039. Hamamatsu Photonics K. K.. Shizuoka-Ken. Japan). When the frit at one end of the capillary tube was formed. it was
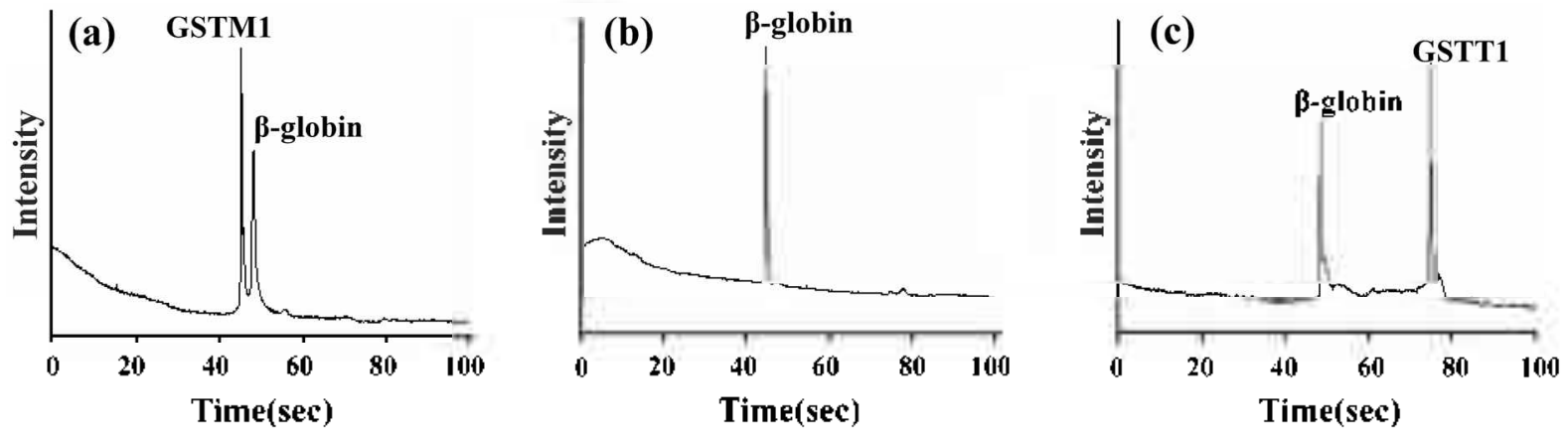

Figure 5. Analysis of PCR products of GSTml, $\beta$-globin, and GSTT1 by using PDMS microchip. (a) GSTMl (215 bp), $\beta$-globin (268 bp), (b) $\beta$-globin, (c) $\beta$-globin, GSTTl (480 bp). Electric field strength: $250 \mathrm{~V} / \mathrm{cm}$, separation channel length: $3.5 \mathrm{~cm}$, channel size: $80 \mu \mathrm{mm}$ width $\times 50 \mu \mathrm{m}$ depth, numing bufter, $1.2 \%$ PEO containing $3.0 \mu \mathrm{g} / \mathrm{mL}$ of ethidium bromide in IX TBE. 
rinsed with ethanol by positive pressure with a syringe to remove the unreacted IRGACURE solution.

The capillary tube was filled with silica beads by drawing a bead/water slurry toward the frit by using the syringe. Then. the column was rinsed with I $\mathrm{M} \mathrm{HCl}$ to hydrolyze the surface of the silica and the capillary wall. Hydrolyzed TEOS solution was prepared by adding $0.1 \%(\mathrm{v} / \mathrm{v})$ of $\mathrm{HNO}_{3}$ to a $27 \%$ solution of TEOS in water. and heating to $60^{\circ} \mathrm{C}$ for $10 \mathrm{~min}$ and then $80^{\circ} \mathrm{C}$ for $60 \mathrm{~min}$ with stirring at $200 \mathrm{rpm}$.

DNA extraction procedure. New miniaturized extraction tool was conditioned with $\mathrm{MeOH}$ for $30 \mathrm{~min}$. For each extraction. extraction tool was rinsed with elution buffer (TE) for $30 \mathrm{~min}$, followed by $\mathrm{GuHCl}$ load solution. The extraction procedure itself consisted of load, wash and elution steps. Before the load step, whole blood $(3.0 \mu \mathrm{L})$ was lysed by mixing with $220 \mu \mathrm{L}$ of $10 \%$ Triton-X 100 and $20 \mu \mathrm{L}$ of proteinase $\mathrm{K}$ and then water bath at $55^{\circ} \mathrm{C}$ for $25 \mathrm{~min}$. A 50 $\mu \mathrm{L}$ of the lysate was passed through the extraction tool. Protein and possible PCR inhibitors that were adsorbed onto the silica during the load step were removed by passing 70 $\mu \mathrm{L}$ of the wash buffer (2-propanol/ $\mathrm{H}_{2} \mathrm{O}, 80 \%$ ) through the extraction tool. Finally, DNA was eluted in a low ionic strength TE buffer. After elution of DNA from whole blood. the extraction tool was rinsed with load solution for $5 \mathrm{~min}$ to prepare the bead surface for a subsequent extraction.

Polymerase chain reaction (PCR) for GSTM1 and GSTT1. The primers for GSTT1, GSTMI, and $\beta$ globin were as follows: GSTT1-forward: TCACCGGATCATGGCCAGCA, GSTTI-reverse: TTCCTTACTGGTCCTCACATC-TC, GSTMl-fonward: GAACTCCCTGAAAAGCTAAAGC, GSTMl-reverse: GTTG-GGCTCAAATATACGGTGG $\beta$-globin-forward: CAACTTCATCCACGTTCACC, $\beta$ globin-reverse: GAAGAGCCAAG GACAGGTAC. PCR was performed with thermal cycler system (T-CY) using the following protocol; preheating $\left(95^{\circ} \mathrm{C}\right.$ for $15 \mathrm{~min}$ ), 30 cycles at $94^{\circ} \mathrm{C}$ for $1 \mathrm{~min}, 61^{\circ} \mathrm{C}$ for $1 \mathrm{~min}$, and $72^{\circ} \mathrm{C}$ for $1 \mathrm{minl}$. with a funal extension at $72^{\circ} \mathrm{C}$ for $1 \mathrm{~min}$. The $\mathrm{PCR}$ products were confirmed by the slab gel electrophoresis using $1.0 \%$ agarose gel and by lab-on-a-chip șystem using $1.2 \%$ poly (ethylene oxide) (PEO) gel. ${ }^{21}$

PDMS microchip electrophoresis. Polydimetlyl siloxane (PDMS) oligomer and curing agent (Optrontech Inc.. Changwon. Korea) were mixed at the ratio of $10: 1$ and the resulting bubbles were eliminated by vacuum in desiccator. Then. PDMS was poured on the master and dried at $75^{\circ} \mathrm{C}$ for 2 lirs. For the formation of the microchannel. another PDMS layer was oxidized by for $10 \mathrm{~min}$ by Tesla coil (BD10A. Electrotechnique Production. Inc.. Chicago. IL USA) and bonded to the PDMS layer with engraved channel pattern on it.

DBMA-100 (Digital Bio Techunology. Korea) equipped with DPSS laser (532 $\mathrm{nm} .10 \mathrm{~mW}$ ) and DBHV-100 high voltage supplier was used. A double-T shape PDMS microchip with long channel length of $3.5 \mathrm{~cm}$. channel width of 80 $\mu \mathrm{m}$. and channel depth of $50 \mu \mathrm{m}$ was positioned in place inside DBMA-100 for DNA detection ${ }^{20-4}$ A $6 \mu$ L of PCR product was injected by the pinched injection mode and detected at the long channel with $250 \mathrm{~V} / \mathrm{cm}$. PDMS microchip was cleaned with DI water, $0.01 \mathrm{M} \mathrm{HCl} .0 .10 \mathrm{M} \mathrm{NaOH}$, IXTBE for $5 \mathrm{~min}$, respectively. prior to the loading of $1.2 \%$ $\mathrm{PEO}$ containing of $3 \mu \mathrm{g} / \mathrm{mL}$ of $\mathrm{EB}$ to the long channel.

The fluorescence signal from PCR product was collected with a $10 \mathrm{X}$ microscope objective (Nikon, Japan) into the photomultiplier module (H5784-02. Hamamatsu. ShizuokaKen. Japan) and transferred directly through a low-pass filter to an $\mathrm{A} / \mathrm{D}$ interface board (National Instrument $\mathrm{Co}$. TX, USA). The control of the high-voltage power supply and data collection at $10 \mathrm{~Hz}$ was performed by in-house LabView program with an IBM compatible computer.

Acknowledgment. This work was supported by Kyungnam University Foundation Grant. 2006

\section{References}

1. Kim. D. E.: Teong. Y. T. Bull. Korem Chent Soc. 2006. 27. 1618.

2. Kang. S. H.: Jang. S.: Y1. H. K. Bull. Korew Chent Soc. 2005.49. 537.

3. Kim, J. M.: Lee. M. Y.: Kim, Y. Z. Bull Korean Chem. Soc, 2005. 26,285 .

4. Jang. S.: Cho. K.: Chae. J. S.: Kang. S. H. Bull. Konew Chen. Soc. 2004.25 .757$.

5. Wolfe. K. A.: Breadmore. M. C.: Ferrance. I. P.: Power. M. E.: Conroy. J. F.: Norris. P. M.: Landers. T. P. Electrophoresis 2002. 23. 727

6. Lin, Y. W. Huang. M. F.: Chang. H. T. Electrophoresis 2005. 26. 320

7. Wu, Q. Bienvenue. J. M.; Hassan, B. J.: Kwok. Y. C.: Giordano. B. C.: Norris. P. M.: Landers. J. P.: Ferrance. J. P. Anal. Chent. 2006. 78.5704

8. Roussela. Y: Wilksa. M.: Harrisb. A.: Meinc. C.: Tabaqchali. S Jounal of Aforobiological thethods $\mathbf{2 0 0 5}, 62.71$

9. Shimelis, O.: Zhou, X.; Li. G.: Giese, R. W. J. Chomatog: At 2004. 1053,143 .

10. Trochimchulia. T: Fotheringhama. T.: Toppb. E.: Schrafta. H.: Leunga. K. T. Jonmal of Microbiological Methods $2003.5+165$.

11. Cler. L: Bu. D.: Lewis. C.: Euhus. D. Molectlor and Cellutor Probes 2006, 20. 191

12. Castella, V: Simonin. N. D.: Casadevall, C. B.; Mangin, P. Formsic Science Intemational 2006. 156, 70.

13. Yoza. B.: Arakaki. A.: Matsunaga. I. Jommal of Biotecholog 2003. 101. 219

14. Yoza. B.: Arakaki. A.: Manuyama. K.: Takeyama. H.: Matsunaga. $\mathrm{T}$. Jownal of Bioscience and Bioengineering $2003,95,21$

15. Yoza. B.: Matsumoto, M.; Matsunaga. T. J. Bioteclmol. 2002, 94. 217 .

16. Nakagawaa. T.: Tanakaa. T.: Niwab. D.: Osakab. T.: Takeyamaa. H.: Matsunagaa. T. Jonmal of Biotechnolog 2005.116 .105$.

17. Tian. H.: Hühnner. A. F. R.: Landers. I. P. dinalytical Biochemistn 2000. 283,175

18. Breadmore, M. C.: Wolfe, K. A.: Arcibal, I. G.: Leung, W. K: Dickson. D.: Giordano. B. C.: Power, M. E.: Ferrance J. P. Feldman, S. H.: Norris. P. M.: Landers. J. P. Anal Chent 2003. 75. 1880.

19. Cotton. S. C.: Sharp. L.: Little. J.: Brockton. N. Am. J. Epidemiol 2000. 15]. 7 .

20. Cha. I. H.: Kwon, J. J.; Park, K. K. J. Lor: Oral Maxillofac. Sug 2002. 28,364

21. Fung. E. N.: Yeung. E. S. Anal. Chem 1995. 67. 1913

22. Kang. S. H.: Tang. S.: Park. S. K. Bull. Korew Chent. Soc. 2006. $27(9) .1346$

23. Kang. C. M.: Back. S. K.: Choi. B. O.: Lee. S.: Chung. K.: Kang. S. H.: Kim. Y. S. Bull. Korean Chem. Soc. 2006. 27. 1239

24. Kang. C. M: Back. S. K: Song, I. G.: Choi, B. O; Chang. J.: Cho. K.: Kim. Y. S. Bull. Konan Chem Soc. 2006, 27(4). 519. 